\title{
Investigating the effect of elevated temperatures on the properties of mortar produced with volcanic ash
}

DOI:

10.1007/s41062-020-0274-4

\section{Document Version}

Accepted author manuscript

Link to publication record in Manchester Research Explorer

\section{Citation for published version (APA):}

Al Hamd, R. (2020). Investigating the effect of elevated temperatures on the properties of mortar produced with volcanic ash. Innovative Infrastructure Solutions, 5(25). https://doi.org/10.1007/s41062-020-0274-4

\section{Published in:}

Innovative Infrastructure Solutions

\section{Citing this paper}

Please note that where the full-text provided on Manchester Research Explorer is the Author Accepted Manuscript or Proof version this may differ from the final Published version. If citing, it is advised that you check and use the publisher's definitive version.

\section{General rights}

Copyright and moral rights for the publications made accessible in the Research Explorer are retained by the authors and/or other copyright owners and it is a condition of accessing publications that users recognise and abide by the legal requirements associated with these rights.

\section{Takedown policy}

If you believe that this document breaches copyright please refer to the University of Manchester's Takedown Procedures [http://man.ac.uk/04Y6Bo] or contact uml.scholarlycommunications@manchester.ac.uk providing relevant details, so we can investigate your claim.

\section{OPEN ACCESS}




\title{
Investigating the effect of elevated temperatures on the properties of mortar produced with volcanic ash
}

\begin{abstract}
During the recent years, the use of pozzolanic materials (e.g. volcanic ash) in concrete and cement manufacturing has increased significantly since it can reduce the environment hazard associated with using Portland cement. In this paper, the effect of elevated temperatures on the physical and mechanical characteristics of building mortar produced with volcanic ash is experimentally explored. In order to evaluate the performance of the mortar, four different proportions of volcanic ash $(0,5,15$ and $25 \%)$ -as weight replacement of the cement- were prepared. A series of tests were conducted after 28, 90 and 120 days under different temperatures $\left(25,200,500\right.$ and $\left.800 C^{\circ}\right)$. This paper demonstrates that the replacement of cement by a proportion of volcanic ash can sustain an acceptable level of compressive strength and improve the overall characterization of the mortar while reducing the amount of $\mathrm{CO}_{2}$ released. The mortar with $15 \%$ ratio of the volcanic ash replacement showed better flexural and the tensile strength. This paper also heights that the volcanic ash replacement affects the late-age properties of the mortar more than the early-age ones at both ambient and elevated temperatures.
\end{abstract}

Keywords: Elevated temperature, Volcanic ash, natural pozzolan, Mortar. 


\section{Introduction}

Concrete exhibits superior resistance compared to more popular construction materials like steel and wood. Being non-combustible, concrete forms a barrier that prevents the further spread of fire, hence its use does not increase risk of fire in buildings[1]. Concrete from Portland cement is commonly utilized in the construction of buildings, as it is capable of satisfying the crucial need for safety from fire hazards, in a manner better than most of its competitor materials [2,3]. The change in concrete's temperature, and the changes stemming from its exposure to fire, have been a key interest for the researchers in the field of fire safety. The main ingredients of concrete, including the paste of cement, undergo a series of reactions of decomposition, which are in most cases permanent and cannot be reversed.

Additionally, previous studies have investigated some of the physical and mechanical changes of the mortar subjected to high temperatures. These studies included studying the influence of the compressive strength on the color change in mortars [4]; the influence of the temperature on pore structure; the concrete permeability; the mechanical properties of concrete of normal strength and also on concrete of high performance $[5,6]$ and the behavior of spalling in structural elements like columns or beams [1,7-10]. The thermal response of concrete under elevated temperatures is dependent on the proportions used in its mix, and on the characteristics of its constituents [11]. Exposure to elevated temperatures is a critical process of physical deterioration, and one that inflicts direct effects on the durability of the structure of concrete. Upon exposure to elevated temperatures, concrete could exhibit detrimental failures in its structural integrity [9]. The major outcomes resulting from exposure to high level of temperatures include the changes that occur in the concrete color and spall, the losses in mass or weight of the concrete, and the deterioration in performance due to the degradation of the compressive strength. The building materials might be exposed to the effects of elevated temperatures during fire incidences, or inside reactors and when in proximity to furnaces. The deformation, the elastic modulus, aggregate interlock and bonds between the cement paste and the aggregate are also influenced by high temperatures [2].

The rate at which temperature increase is another factor affecting the type and extent of the changes occurring in the mechanical properties of concrete when subjected to high temperatures. When concrete is subjected to an elevated temperature ranging between 100 and $200^{\circ} \mathrm{C}$, the evaporation of free water takes place slowly; hence structural damage does not occur. On the other hand, when heating takes place rapidly, the resulting higher vapor pressure leads to the formation of cracks in the surface morphology of the concrete. After the temperature reaches $400^{\circ} \mathrm{C}$, the concrete was shown to begin to lose its compressive strength [12].

At temperatures ranging from 400 to $500^{\circ} \mathrm{C}$, concrete was shown to exhibit a reduction in its compressive strength by approximately 15 to $70 \%$ of the value in concrete that had not been subjected to heating [3]. As the temperature is increased, the evaporation of the trapped water in the paste of the concrete starts to take place at around $400 \mathrm{C}^{\circ}$; therefore, leading to the dehydration of calcium silicate hydrate $(\mathrm{CSH})$, which is the compound used in concrete mixture to achieve the bonding together the diverse components constituting the concrete paste. When dehydration takes place in the crystals of $\mathrm{CSH}$, it was shown to irreversibly lower the strength of the concrete. At 530 $\mathrm{C}^{\mathrm{o}}, \mathrm{Ca}(\mathrm{OH})_{2}$ converts to $\mathrm{CaO}$, resulting in a shrinkage in the volume of the concrete paste by approximately $33 \%[1,10]$.

Khoury et al reported significant changes in the chemical and physical structure of concrete [13], when exposed to high temperatures. They observed that when the binding 
paste of concrete faces temperatures above $110^{\circ} \mathrm{C}$, it causes the chemically bound water to be released from calcium silicate hydrates. Internal micro-cracks were reported to occur within the structure of the concrete, which was observed particularly when the temperature increased up to $300^{\circ} \mathrm{C}$ [14], which was due to dehydration of calcium silicate, and the expansion of the aggregates under high levels of temperature.

The use of pozzolanic materials (e.g. volcanic ash) is becoming more appealing as they reduce the cost of cement, results in a better durability, retard reaction (important with hydraulic structures) and most importantly removes the waste product from environment $[10,12,15]$. There are limited studies on the effect of elevated temperature on the mortar containing natural volcanic ash; therefore, this paper aims at studying the physical and mechanical properties of mortar containing different percentages as a replacement for cement.

\section{Description of Volcanic Ash in Concrete}

Volcanic ash (rock dust) powder is a naturally existing volcanic rock that consists of more than 70 types of minerals. Volcanic ash rock dust powder Azomite is mined from ancient volcanic ash deposits in central region of the State of Utah, USA. It is used in many countries including China, Mexico, Germany, Italy, and Greece, to achieve the reduction in cost and improvement of the durability and the quality of concrete [16].

The use of volcanic ash is merited by its chemical or pyro chemical properties, also its physical properties, including the light color, friability, fine size and angularity of its particles. In ceramics, it is used as abrasive, in cellular blocks, concrete, and lightweight aggregates and in vitreous enamels and glass in general.

pozzolanic properties: volcanic ash is one of natural pozzolana, and has pozzolanic properties with silica oxide $\left(\mathrm{SiO}_{2}\right)$ content, which influences significantly the strength of the designed concrete [16].

One of the most significant aspects that would be affected by the addition of the volcanic ash to mixture is the development of the strength. The main factors that affects the development in the strength in mortar with volcanic ash are illustrated below $[17,18]$ :

1. The volcanic ash as admixture

2. The volcanic ash as aggregate.

3. The fineness of the natural Pozzolana has a significant effect on early strength development.

4. The process of curing (and the related parameters) plays an important role in the development of strength of any binding material. Longer curing time (in addition to the type of curing) provides higher strength values than when the same concrete mix is cured for a shorter time period. Lime Pozzolana mixtures in particular, are affected by curing largely, because of their slow strength gain versus that of cement. The process and parameters of curing also affect the permeability of pozzolanic mixtures, which is reflected in the robustness of the structure [18].

The physical and chemical characteristics of the volcanic ash used in this study are shown in Table 4.

The pozzolanic behavior likability of the used volcanic ash was assessed based on the standard specification test ASTM C618. Chemical analysis results showed that the summation of the $\mathrm{SiO}_{2}, \mathrm{Al}_{2} \mathrm{O}_{3}$, and $\mathrm{Fe}_{2} \mathrm{O}_{3}$ contain was $78.65 \%$, which fulfills the minimum prerequisite of $70 \%$, fixed by the standard specification [19]. Additionally, the amount of $\mathrm{SO}_{3}$ is 0.21 , and the loss on ignition (LOI) is 6.43 more than that of 
cement, which is within the limits of the ASTM C618 [20]. It can also be noted that the strength activity index is utilized to assess the reactivity between the cement and the mineral admixture used.

\section{Experimental Program}

\subsection{Material}

In this section, the used materials including cement, fine aggregate, volcanic ash and chemical admixtures characteristics are explored as shown below.

A- Cement: Ordinary Portland Cement Type 1 (OPC) was used in this study ( ASTM C150 - Type 1) [21]. The used cement was checked according to IOS 5:1984 [22] as shown in Tables 1 and 2 .

B- Aggregate: In this research, natural sand was used as a fine aggregate. The sand grading shown in Table 3, according to IOS No.45/1984 [23]. The test results for the physical and chemical properties of the sand used including absorption $\%$, specific gravity, dry loose-unit weight $\mathrm{kg} / \mathrm{m}^{3}$, and sulfate content were found to be $2.00 \%, \mathrm{SO}_{3} 2.69,1725 \mathrm{~kg} / \mathrm{m}^{3}$, and $0.24 \%$, respectively.

C- Volcanic Ash (VA): The AZOMITE is a mineral composition came from the combination of seawater and fed by hundreds of rivers rich in minerals, which present in volcanic ash and this geologic characteristic is an outcropping known as a "hogback" (see Fig.(1)). Table 4 shows Chemical analysis of the volcanic ash.

D- Chemical Admixture: Glenium 51 (high range water reducing admixture) was used as a super-plasticizer for the mixture, Table 5 show the main characteristics of the product.

\subsection{Mix design and sample preparation}

According to ASTM C109 [24], all the test specimens were prepared then the standard procedure of all mixing was carefully performed according to ASTM C-305.The mix proportions used in this paper for cement: sand: W/C: Glenium 51 are 1: 2.75: 0.35:2$3 \%$. Table 6 shows the four concrete mixtures with various proportions of VA ranging from $0 \%, 5 \%, 15 \%$, and $25 \%$. The choice of these ratios is according to the limited cement percentage to be replaced as adding more than $25 \%$ would results in a very low strength of the mortar [16]. To examine the effect of VA replacement for cement (for 28, 90 and 120 days of curing) the following tests were performed; compressive strength, flexural strength, ultrasonic pulse velocity, absorption, and weight loss, cubes $50 \times 50 \times 50 \mathrm{~mm}$, and prisms 40x40x160 mm.

\section{Testing procedure and method}

An experimental planner was designed to investigate the physical and mechanical characterization of blended cement mortar containing VA following exposure to elevated temperatures. For this purpose, the electric arc furnace shown in Fig. (2) was used. Four mixtures with $0 \%, 5 \%, 15$, and $25 \% \mathrm{VA}$ as a replacement by weight for cement were prepared. A total of 192 cubes and 144 prisms were tested to examine the physical and mechanical properties of the blended cement mortar containing VA. During the first stage, the specimens were retained after casting in the molds for $24 \mathrm{hr}$. at a room temperature of $25^{\circ} \mathrm{C}$. After de-molding the specimens, they were cured for 28,90 , and 120 days in water. In the second stage, the specimens were dried at $25 \mathrm{C}^{\circ}$ for 24 hours first, then exposed to different elevated temperatures $\left(200,500\right.$, and $\left.800^{\circ} \mathrm{C}\right)$ for $1.5 \mathrm{hr}$. at a rate of $10{ }^{\circ} \mathrm{C} / \mathrm{min}$, as shown in Fig (3). At the last stage, the specimens 
were left in the furnace to cool down gradually. Finally, the following tests were conducted:

\subsection{Slump flow test}

Slump flow test was followed the ASTM C1437 [25] for the mortar flow of all mixes and was performed by using the flow table equipment.

\subsection{Absorption test}

Absorption test followed the ASTM C642 testing standard [26]. The average water absorption of the three cubs for each mixes and ages was calculated following Equation 1 calculated according to ASTM C642 [26]:

$$
\text { Absorption ratio }=\frac{(\text { wet weight }- \text { dry weight })}{\text { dry weight } \times 100} \ldots \ldots . \text { Equation } 1
$$

\subsection{Loss in Weight}

The weight of each sample before and after exposing to elevated temperatures was measured. Weight loss was then calculated as shown in Equation (2) according to [11]

$$
W_{\text {loss }}=\frac{\text { Standard weight }- \text { Weight at exposure temprature }}{\text { Standard weight } \times 100} \ldots \ldots \text { Equation } 2
$$

\subsection{Compressive Strength}

Compressive Strength test was performed according to ASTM C109/ C109M-05 testing standard [24] on $50 \times 50 \times 50 \mathrm{~mm}$ cubes, using a digital compression testing machine $2000 \mathrm{kN}$ in capacity. The test was conducted at ages of 28, 90 and 120 days (three specimens were tested for each age).

\subsection{Flexural strength}

The flexural strength test was performed according to ASTM C348-02 testing standard [27], on $40 \times 40 \times 160 \mathrm{~mm}$ prisms, under central line loading using flexural testing machine $10 \mathrm{kN}$ in capacity.

\subsection{Ultrasonic pulse velocity}

The ultrasonic pulse velocity [28] of three $40 \times 40 \times 160 \mathrm{~mm}$ prism specimens, was determined automatically by using a device that measured the time of ultrasonic waves to pass throughout the tested specimen length, from the wave transmitter to the receiver nozzle. Then, the Equation 3 was used to calculated the wave speed [28].

$$
V=(h / t) \times 10^{6} \ldots \ldots . . . \text { Equation } 3
$$

\section{Results and discussion}

\subsection{Flow of mortar}

Since the fineness and the large surface area of pozzolan materials, might result in lower flow and higher water demand. This would lead to a lower workability with increasing percentage of VA. As a result of the fineness of pozzolan materials particles greater amount of water demand obtain to the desired consistency, and the reduction in flow in proportion to their amount [29]. Table 6 shows the flow of all mortar mixes, the VA-0 mix was $112 \%$ only when using $2 \%$ Glenium 51 as a super-plasticizer and to ensure 
getting the same flow for all mixes the a higher percentage of the super-plasticizer was used, this is in line with [29] findings.

\subsection{Absorption}

Absorption results of specimens at 28 days age for all four tested sets under the effect of elevated temperatures is shown in Fig (4). The results demonstrate an increase in absorption with the increase of temperature and percentage of replacement of VA at 28 days age, except for the higher temperature case $\left(500\right.$ and $\left.800^{\circ} \mathrm{C}\right)$ where the control specimens exhibit the maximum absorption. Heating the specimen would increase the rate of absorption, as the water within the concrete would start evaporating after $100{ }^{\circ} \mathrm{C}$ [30]. The water within the hydrated cement can be classified into two categories; the evaporable water (water in the capillary pores and some water in the gel pores) and Non-evaporable water (nearly all chemically combined water and some water not held by chemical bonds)[18]. The higher absorption for the control mixture at high temperatures is an indicator that the mortar with a higher percentage of VA replacement is more durable than the normal mortar at post-fire condition as the higher water absorbed by mortar the less durable it becomes.

\subsection{Loss in weight}

Fig (5) to (7) demonstrate the effect of various elevated temperatures on the weight loss of all mixes. It can be seen that the unit weight values decrease with increasing temperature for all mixes, as a result of weight reduction taking place in the specimens after releasing their water contain [28]. Eventually, after the water being released from the cement paste, air void would start forming. The concrete specimens containing VA experienced higher weight losses than the control concrete specimens, this finding is in line with reference [10]. At temperature range between 20 to $200^{\circ} \mathrm{C}$, the weight loss is fundamentally due to evaporation of moisture from the surface of concrete specimen to the atmosphere. The specimens exposed to $500{ }^{\circ} \mathrm{C}$ has shown the highest loss in weight that could be a result of the evaporation of residual moisture content retained at a temperature level of $200^{\circ} \mathrm{C}$. Meanwhile, the degradation in the weight of specimen was lower at a temperature range of $200^{\circ} \mathrm{C}$ to $500^{\circ} \mathrm{C}$ compared to $500^{\circ} \mathrm{C}$ to $800^{\circ} \mathrm{C}$. The evaporation of free water and $\mathrm{CSH}$ water in structure of $\mathrm{CSH}$ and subsequent decomposition of $\mathrm{Ca}(\mathrm{OH})_{2}$ can be the reasons of the percentage of loss in weight. It changes the stiffness and mechanical properties of the substance and might results in a lower compressive strength values [19].

The specimen with maximum percentage of VA replacement 25\% (VA-25) has shown the maximum loss of water, which could be due to higher retention of water content in the presence of volcanic ash. It can also be noted from Figs (5) to (7) the relationship between the percentage of loss weight with ages. Moreover, it can be seen that the specimens cured for 120 days age have the highest percentage of loss weigh. Therefore, the increase in the percentage of loss weight was observed with increased specimens curing age and that can be due to the saturation of the specimens increased with the time of curing.

\subsection{Compressive strength}

The main components of the hydrated cement paste are Calcium Silicate Hydrate, Calcium Hydroxide, and Calcium Sulfate Aluminate Hydrate. Besides that, the saturated paste encloses a significant amount of free, capillary and gel water. Therefore, the effect of $\mathrm{Ca}(\mathrm{OH})_{2}$ can be reduced by using different pozzolans, such as fly ash, slag, silica fume, clay, and volcanic ash, as a replacement of cement in concrete. $\mathrm{SiO}_{2}$ present 
in these pozzolans reacts with $\mathrm{Ca}(\mathrm{OH})_{2}$, and a byproduct of hydration reaction forms calcium silicate hydrates. As a result, the amount of $\mathrm{Ca}(\mathrm{OH})_{2}$ is reduced, and C-S-H is increased, which improves the performance at elevated temperatures[31,32].

Figs (8) to (10) displays the relationship between compressive strength and the effect of elevated temperatures for different percentages of replacement VA with cement. It can be seen that the compressive strength would increase with curing time; meanwhile, compressive strength decreases with increasing the amount of VA replacement. Therefore, the minimum value of compressive strength was for the mix with higher VA contain $(25 \%)$. This makes sense since replacing the cement with VA reduces the cement content in the mix at short-term. However, looking at the long-term durability the pozzolanic action of VA helped to improve the strength [31], keeping in mind that the reduction of strength in blended cement due to the replacement is not compensated in the current study.

Figs (8) to (10) illustrate that the compressive strength increased between 25 to 200 ${ }^{\circ} \mathrm{C}$, this can be due to the formation of Tobermorite (calcium silicate hydrate mineral), which is formed by reaction between un-hydrated VA particle at high temperature. At temperature range 200 to $500{ }^{\circ} \mathrm{C}$, there is a decrease in the compressive strength for all specimens and for all curing ages, but the highest reduction occurred at 28 day (see Fig (11)). This reduction can be due to the pore structure roughening in concrete [33]. All mixes at $500-800 \circ \mathrm{C}$ temperature show severe loss in compressive strength. The severe deterioration in mortar is with reason to the dissociation of CSH gel [32].

\subsection{Flexural strength}

Figs (12) to (14) show the relationship between the flexural strength and the effect of elevated temperatures, for different percentages of replacement VA with cement. All the mixes show improved flexural strength with curing time. The results show the decrease in the flexural strength with the increase in the amount of the VA replacement at $25{ }^{\circ} \mathrm{C}$. The decrease in the flexural strength at 28 days were 13.34, 5.92 and $24.52 \%$ for VA-5, VA-15 and VA-25, receptively. Specimens with $15 \%$ VA as a replacement had the best result. Fig. 12 shows the effect of different temperatures on flexural strength at $800^{\circ} \mathrm{C}$. The residual flexural strength was $75.74,76.34,87.53$ and $87.85 \%$ for VA-0, VA-5, VA-15 and VA-25, receptively. The percentage of the residual flexural strength was calculated relatively to retained flexural strength with respect to the unheated specimen flexural strength $\left(25^{\circ} \mathrm{C}\right)$. At 90 day, the residual flexural strength values for specimens were $66.66,79.71,91.5$ and $95.1 \%$, for VA-0, VA-5, VA-15 and VA-25, receptivity. At $800{ }^{\circ} \mathrm{C}$ and at 120 day, the values were 64.2, 79.1, 89.0, and 90.38 for VA-0, VA-5, VA-15 and VA-25, receptivity. The loss of strength observed at higher temperatures might be attributed to the loss of bound water, increased porosity, and consequently, increasing permeability [28].

\subsection{Ultrasonic pulse velocity}

As seen in Fig. (15) to (17), the Ultrasonic pulse velocity (UPV) of the specimens that were used in the study deteriorated due to increasing temperature and percentage of VA replacement, resulting a lower in UPV (especially at $800^{\circ} \mathrm{C}$ ). This decrease in UPV is due to the degeneration of the $\mathrm{CSH}$ gel at above $500{ }^{\circ} \mathrm{C}$ temperatures, which causes would increase air voids in the specimens cement paste. This would slow down transmission speed of sound waves along of the specimens. The increase in UPV was noticed to be higher for VA-0 specimens at $500{ }^{\circ} \mathrm{C}$ and $800{ }^{\circ} \mathrm{C}$, meanwhile the 
maximum decrease in UPV was for VA-25. This reduction in the UPV can be due to the formation of a porous structure as a result of the decomposition the C-S-H gel [28].

\section{Conclusions}

This study has presented an experimental program set to explore the effect of elevated temperatures effects on the mechanical and physical properties of cement mortar containing volcanic ash. The results of 192 cubes and 144 prisms tested postheating after exploring to four different temperatures including room temperature $\left(25,200,500\right.$ and $\left.800^{\circ} \mathrm{C}\right)$. Three different weight replacements of the cement were considered $(5,15$ and $25 \%)$ of the volcanic ash along with the control specimens. For the limitations for this research, the following conclusions can be drawn:

1. The addition of volcanic ash to the mixtures showed a limited reduction in the mechanical and physical properties, which indicates that it could be suitable to use as partial replacement of cement, paste and mortar to reduce the carbon emission resulting from the Portland cement reactions.

2. At $800^{\circ} \mathrm{C}$, the control specimens exhibit a higher water absorption compared to the ones contain volcanic ash, which denote that they are more durable since the higher water absorbed by results in less durable mortar.

3. The concrete becomes more brittle after exposure to elevated temperatures due to the loss of water and show changes in color and density loss. When the temperature exceeded $500{ }^{\circ} \mathrm{C}$, the fine cracks on concrete specimen appear on surface.

4. The compressive strength of mortar at $200^{\circ} \mathrm{C}$ heating was increased compared to the initial strength determined at $25^{\circ} \mathrm{C}$, for all mixes due to the formation of Tobermorite.

5. At $500^{\circ} \mathrm{C}$, the compressive strength decreased in all cases in relation to the value determined before post-heating. However, at $800^{\circ} \mathrm{C}$, the maximum value of reduction in the compressive strength was below the value determined on unexposed specimens in all cases, with the maximum drop reaching $79.54 \%$ for VA- 0 at 28 days age, versus $59.32 \%$ and 52.76 for VA-25 and VA-0, at 90 days age. As the temperature, goes higher the bond within cement paste is weaken causing the mortar to be more brittle.

6. At temperatures above $500{ }^{\circ} \mathrm{C}$, the amount of air voids in the specimens' were increased, due to the degeneration of the $\mathrm{CSH}$ gel and that decreases the compressive strength and flexural strength, and increases the weight loss.

\section{References}

[1] Drzymała T, Jackiewicz-Rek W, Tomaszewski M, Kuś A, Gałaj J, Šukys R. Effects of High Temperature on the Properties of High Performance Concrete (HPC). Procedia Eng 2017;172:256-63. doi:10.1016/j.proeng.2017.02.108.

[2] Ibrahim RK, Ramyar K, Hamid R, Taha MR. The effect of high temperature on mortars containing silica fume. J Appl Sci 2011;11:2666-9. doi:10.3923/jas.2011.2666.2669.

[3] Morsy MS, Rashad AM, Shebl SS. Effect of elevated temperature on compressive strength of cement mortar. Build Res J 2008;56:173-85.

[4] Yüzer N, Aköz F, Öztürk LD. Compressive strength-color change relation in mortars at high temperature. Cem Concr Res 2004. doi:10.1016/j.cemconres.2004.01.015.

[5] Li M, Qian CX, Sun W. Mechanical properties of high-strength concrete after fire. Cem Concr Res 2004;34:1001-5. doi:10.1016/j.cemconres.2003.11.007.

[6] Noumowe AN, Siddique R, Debicki G. Permeability of high-performance concrete subjected to elevated temperature $\left(600{ }^{\circ} \mathrm{C}\right)$. Constr Build Mater 2009;23:1855-61. 
doi:10.1016/j.conbuildmat.2008.09.023.

[7] Lottman BBG, Koenders EAB, Blom CBM, Walraven JC. Spalling of fire exposed concrete. Heron 2017;62:129-66.

[8] Hertz KD, Sørensen LS. Test method for spalling of fire exposed concrete. Fire Saf J 2005;40:466-76. doi:10.1016/j.firesaf.2005.04.001.

[9] Seshu R, Pratusha A. A Study on Behaviour of Normal Strength Concrete and High Strength Concrete Subjected to Elevated Temperatures. Mag Concr 2013;65:415-21.

[10] Khurram N, Khan K, Saleem MU, Amin MN, Akmal U. Effect of Elevated Temperatures on Mortar with Naturally Occurring Volcanic Ash and Its Blend with Electric Arc Furnace Slag. Adv Mater Sci Eng 2018;2018. doi:10.1155/2018/5324036.

[11] Andrew H. Buchanan C. Structural Design for Fire Safety. University of Canterbury, New Zealand: John Wiley \& Sons; 2002. doi:doi:10.1201/9781420039931.ch37.

[12] Phan LT, Carino NJ. Fire performance of high strength concrete: Research needs. Struct Congr 2000 Adv Technol Struct Eng 2004;103. doi:10.1061/40492(2000)181.

[13] Khoury GA, Majorana CE, Pesavento F, Schrefler BA. Modelling of heated concrete. Mag Concr Res 2002;54:77-101. doi:10.1680/macr.2002.54.2.77.

[14] Hertz KD. Concrete strength for fire safety design. Mag Concr Res 2005;57:445-53. doi:10.1680/macr.2005.57.8.445.

[15] Endait M, Wagh S. Effect of Elevated Temperature on Mechanical Properties of High Strength Concrete Author. Innov Infrastruct Solut 2020;5:1-8. doi:10.1007/s41062019-0254-8.

[16] Siddique R. Properties of concrete made with volcanic ash. Resour Conserv Recycl 2012;66:40-4. doi:10.1016/j.resconrec.2012.06.010.

[17] Karahan O, Hossain KMA, Atis CD, Lachemi M, Ozbay E. Ground Granulated Pumice-Based Cement Mortars Exposed to Abrasion and Fire. Arab J Sci Eng 2017;42:1321-6. doi:10.1007/s13369-016-2403-0.

[18] Samizi M, Josephat J. Utilizing Volcanic Ashes as Partial Replacement of Cement in Concrete Production. Int J Innov Res Dev 2017;6:174-80. doi:10.24940/ijird/2017/v6/i6/jun17108.

[19] Karim MR, Hossain MM, Khan MNN, Zain MFM, Jamil M, Lai FC. On the utilization of pozzolanic wastes as an alternative resource of cement. Materials (Basel) 2014;7:7809-27. doi:10.3390/ma7127809.

[20] ASTM C618-05. Standard Specification for Coal Fly Ash and Raw or Calcined Natural Pozzolan for Use in Concrete, 2005. doi:10.1063/1.4756275.

[21] ASTM C150/C150M-16. Standard Specifications for Portland Cement 2016:1-9. doi:10.1520/C0150.

[22] Iraqi specification. No.5/1984: "Portland cement," 1984.

[23] Iraqi specification. No.45/1984: "Aggregate from natural sources for concrete and construction," 1984.

[24] C109/C109M-13. Standard Test Method for Compressive Strength of Hydraulic Cement Mortars, 2013. doi:10.1520/C0109.

[25] ASTM C 1437-07. Standard Test Method for Flow of Hydraulic Cement Mortar. Annu. B. ASTM Stand., 2009, p. 6-7.

[26] ASTM C642-13. Standard Test Method for Density, Absorption, and Voids in Hardened Concrete, 2013. doi:10.1520/C0642-13.5.

[27] ASTM C348. Standard Test Method for Flexural Strength of Hydraulic-Cement Mortars. Annu B ASTM Stand 1998;04:2-7. doi:10.1520/C0348-14.2.

[28] Demirel B, Keleştemur O. Effect of elevated temperature on the mechanical properties of concrete produced with finely ground pumice and silica fume. Fire Saf J 2010;45:385-91. doi:10.1016/j.firesaf.2010.08.002.

[29] Ahmad SF, Shaikh Z, Naik PH. 11. Portland-pozzolana Cement from Sugarcane Bagasse Ash; KVIC Technology in the Production of Lime and Alternative Cements in India. Lime Other Altern. Cem., 1992. doi:10.3362/9781780442631.011.

[30] Al-Zou'By J, Al-Zboon KK. Effect of volcanic tuff on the characteristics of cement mortar. Ceramica 2014;60:279-84. doi:10.1590/S0366-69132014000200018. 
[31] Hossain KMA. Blended cement using volcanic ash and pumice. Cem Concr Res 2003;33:1601-5. doi:10.1016/S0008-8846(03)00127-3.

[32] Georgali B, Tsakiridis PE. Microstructure of fire-damaged concrete. A case study. Cem Concr Compos 2005;27:255-9. doi:10.1016/j.cemconcomp.2004.02.022.

[33] Chan YN, Peng GF, Anson M. Residual strength and pore structure of high-strength concrete and normal strength concrete after exposure to high temperatures. Cem Concr Compos 1999;21:23-7. doi:10.1016/S0958-9465(98)00034-1. 


\section{List of Tables}

Table 1: Ordinary Portland cement (OPC) chemical composition according to ISO 5/1984

\begin{tabular}{ccc}
\hline Oxides composition & Content\% & ISO 5/1984 \\
\hline $\mathrm{CaO}$ Lime & 61.27 & - \\
\hline $\mathrm{Fe}_{2} \mathrm{O}_{3}$ Iron oxide & 3.12 & - \\
\hline $\mathrm{Al}_{2} \mathrm{O}_{3}$ Alumina & 5.05 & - \\
\hline $\mathrm{MgO}$ Magnesia $_{\mathrm{SgO}}$ Silica & 2.06 & - \\
\hline $\mathrm{SO}_{3}$ Sulphate & 21.27 & $<2.80$ \\
\hline Loss of Ignition & 2.07 & $<4.00$ \\
\hline Insoluble residue & 3.21 & $<1.5$ \\
\hline Lime Saturation Factor, L.S.F. & 1.22 & $0.66-1.02$ \\
\hline $\mathrm{C}_{3} \mathrm{~S}$ Tricalcium Silicate & 0.98 & - \\
\hline $\mathrm{C}_{2}$ S Diacalcium Silicate & 43.42 & - \\
\hline $\mathrm{C}_{3} \mathrm{~A}$ Tricalcium Aluminate & 28.31 & - \\
\hline $\mathrm{C}_{4} \mathrm{AF}$ Tetracalcium Aaluminoferrite & 8.11 & - \\
\hline
\end{tabular}

Table 2: Ordinary Portland cement physical characteristics.

\begin{tabular}{cc}
\hline Physical characteristics & Experimental values \\
\hline Setting time (min), & 3.20 \\
Initial & $4: 40$ \\
Final & 26.4 \\
Compressive strength, MPa & 33.4 \\
7- days & 44 \\
28-days & 0.19 \\
\hline Soundness, $\%$ & 330 \\
\hline Specific surface area, $\mathrm{m}^{2} / \mathrm{kg}$ & \\
\hline
\end{tabular}

Table 3: Sieve analysis of the used sand compared with of IOS No.45/1984.

\begin{tabular}{ccc}
\hline Sieve size ,mm & Cumulative passing, \% & IOS No.45/1984 \\
\hline 10.00 & 100 & 100 \\
\hline 4.75 & 97 & $90-100$ \\
\hline 2.36 & 92.2 & $75-100$ \\
\hline 1.18 & 77 & $55-90$ \\
\hline 0.60 & 52.2 & $35-59$ \\
\hline 0.30 & 10.6 & $8-30$ \\
\hline 0.15 & 2 & $0-10$ \\
\hline
\end{tabular}


Table 4: Chemical composition of the used Volcanic Ash*.

\begin{tabular}{cc}
\hline Oxide composition & Oxide content \% \\
\hline $\mathrm{SiO}_{2}$ & 65.85 \\
\hline $\mathrm{Al}_{2} \mathrm{O}_{3}$ & 11.43 \\
\hline $\mathrm{Fe}_{2} \mathrm{O}_{3}$ & 1.37 \\
\hline $\mathrm{Na}_{2} \mathrm{O}$ & 2.07 \\
\hline $\mathrm{K}_{2} \mathrm{O}$ & 5.23 \\
\hline $\mathrm{CaO}$ & 3.87 \\
\hline $\mathrm{MgO}$ & 0.78 \\
\hline $\mathrm{SO}_{3}$ & 0.21 \\
\hline $\mathrm{BaO}$ & 0.09 \\
\hline $\mathrm{C}$ & 0.61 \\
\hline $\mathrm{H}$ & 0.38 \\
\hline $\mathrm{N}$ & 0.15 \\
\hline $\mathrm{Cl}$ & 0.22 \\
\hline $\mathrm{O}$ & 0.73 \\
\hline $\mathrm{Mn} \mathrm{O}_{2}$ & 0.02 \\
\hline $\mathrm{L} . \mathrm{O} . \mathrm{I}$. & 6.43
\end{tabular}

*values supplied by the manufacturer. Table 5: Characterizations of Glenium 51*

\begin{tabular}{cc}
\hline Characteristics & \\
\hline Density & $1.05-1.16 \mathrm{~kg} /$ liter \\
\hline PH. Value & 6.4 \\
\hline Chlorine Content\% (EN 480-10) & $<0.1$ \\
\hline Colour & dark brown \\
\hline Alkaline Content \% (EN 480-12) & $<3$ \\
\hline Viscosity, cps & at $20^{\circ} \mathrm{C} 138 \pm 30$ \\
\hline
\end{tabular}

$$
\text { * Given by the manufacturer. }
$$

450

Table 6: Mortar mix proportion, percentage of flow

\begin{tabular}{ccccccc}
\hline MIX ID & VA & W/C & $\begin{array}{c}\text { Cement } \\
\mathbf{K g}^{3} \mathbf{m}^{\mathbf{3}}\end{array}$ & $\begin{array}{c}\text { Sand } \\
\mathbf{K g} / \mathbf{m}^{3}\end{array}$ & $\mathbf{S P \%}$ & Flow\% \\
\hline VA-0 & 0 & 0.35 & 400 & 1100 & 2 & 112 \\
\hline VA-5 & 5 & 0.35 & 380 & 1100 & 2 & 112 \\
\hline VA-15 & 15 & 0.35 & 340 & 1100 & 2.3 & 112 \\
\hline VA-25 & 25 & 0.35 & 300 & 1100 & 3 & 112 \\
\hline
\end{tabular}



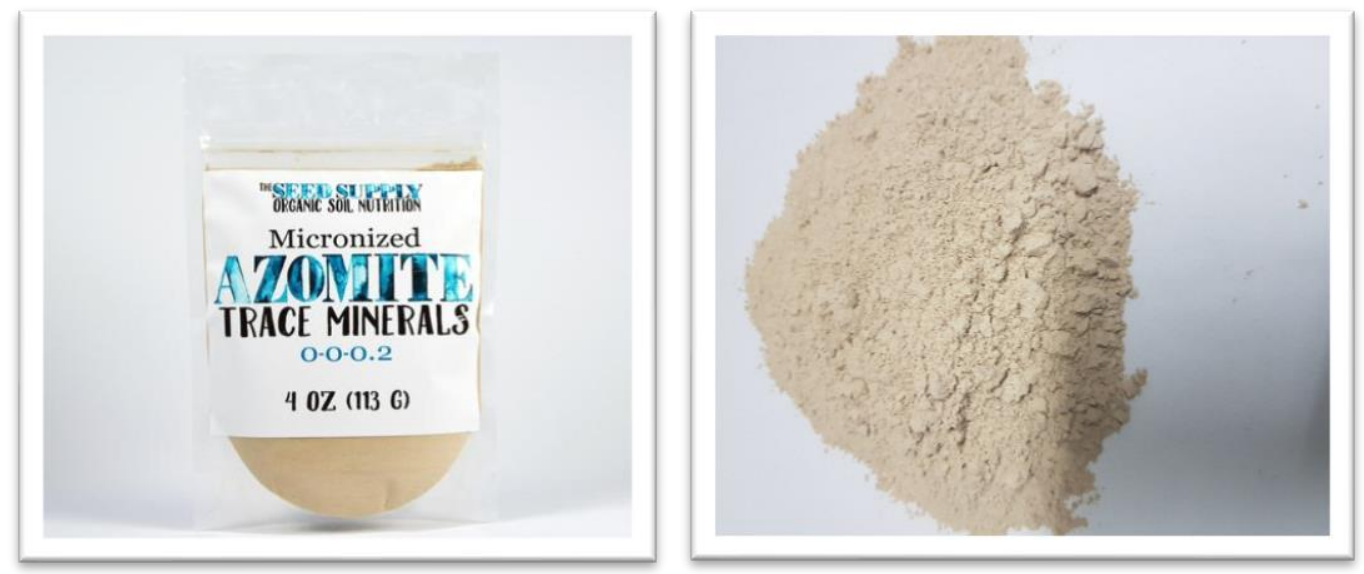

Fig.(1): Mineral Admixture (Volcanic Ash).

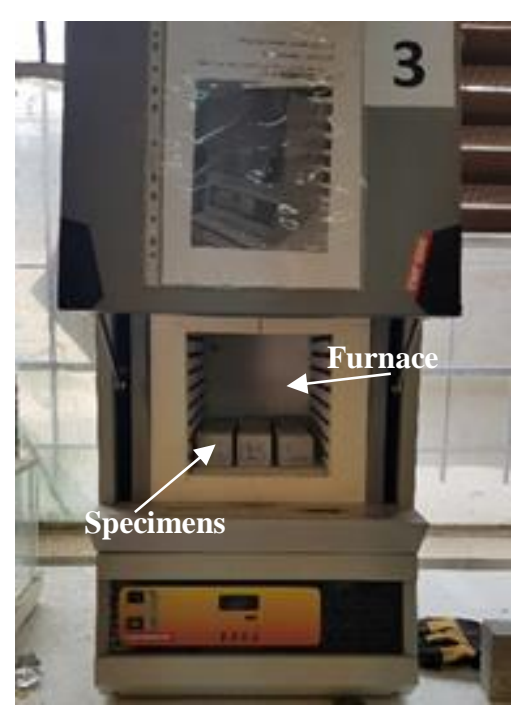

Fig.(2): Mortar specimens in the electric arc furnace

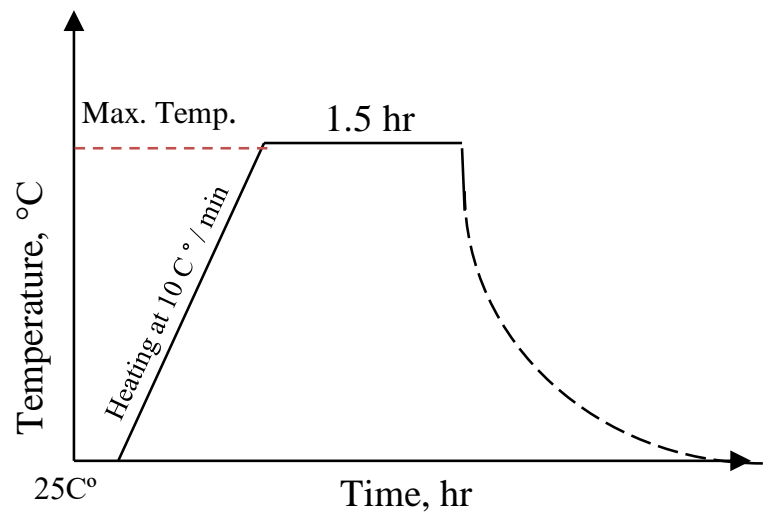




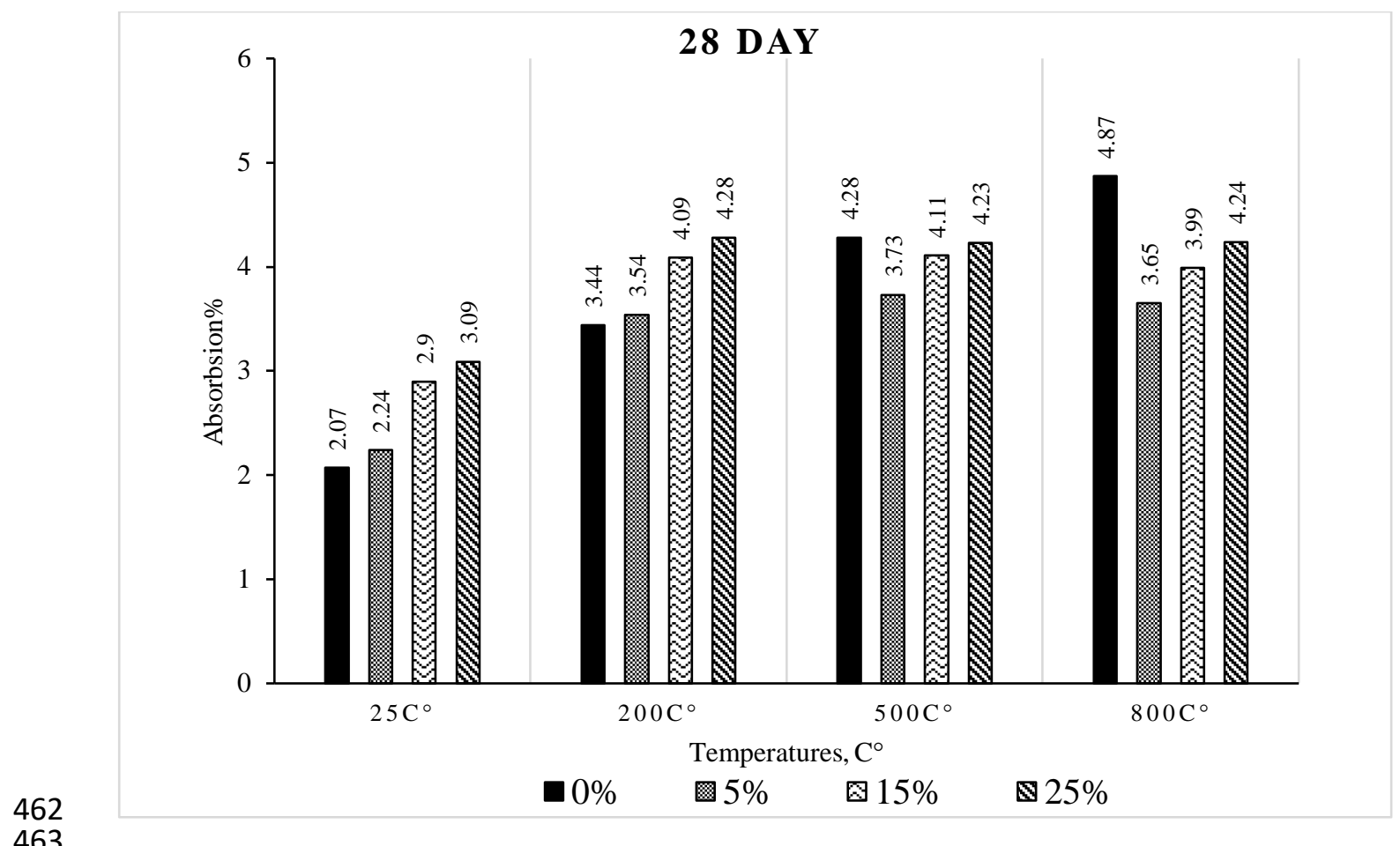

Fig.(4):Relationship between Absorption \% of mortar specimens 28 days age exposed to different temperatures.

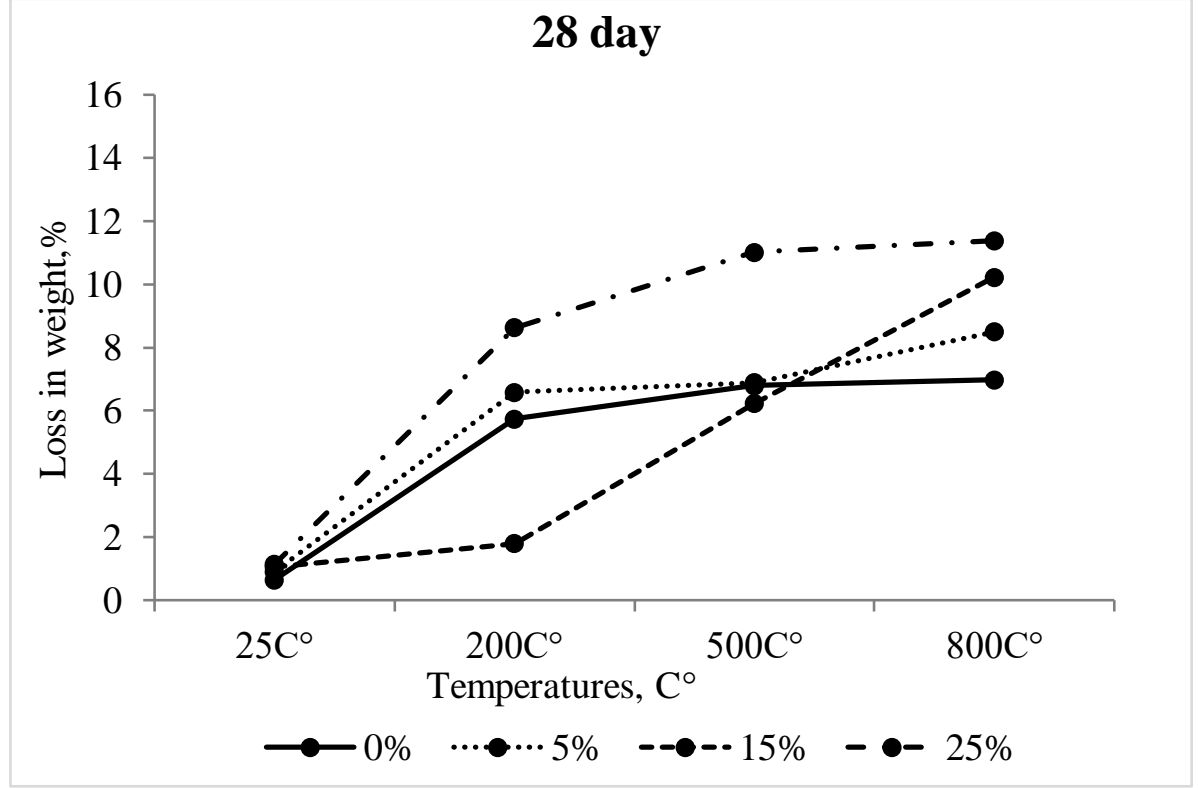

Fig.(5): The percentage of loss in weight of specimens at 28 days age exposed to various temperatures 


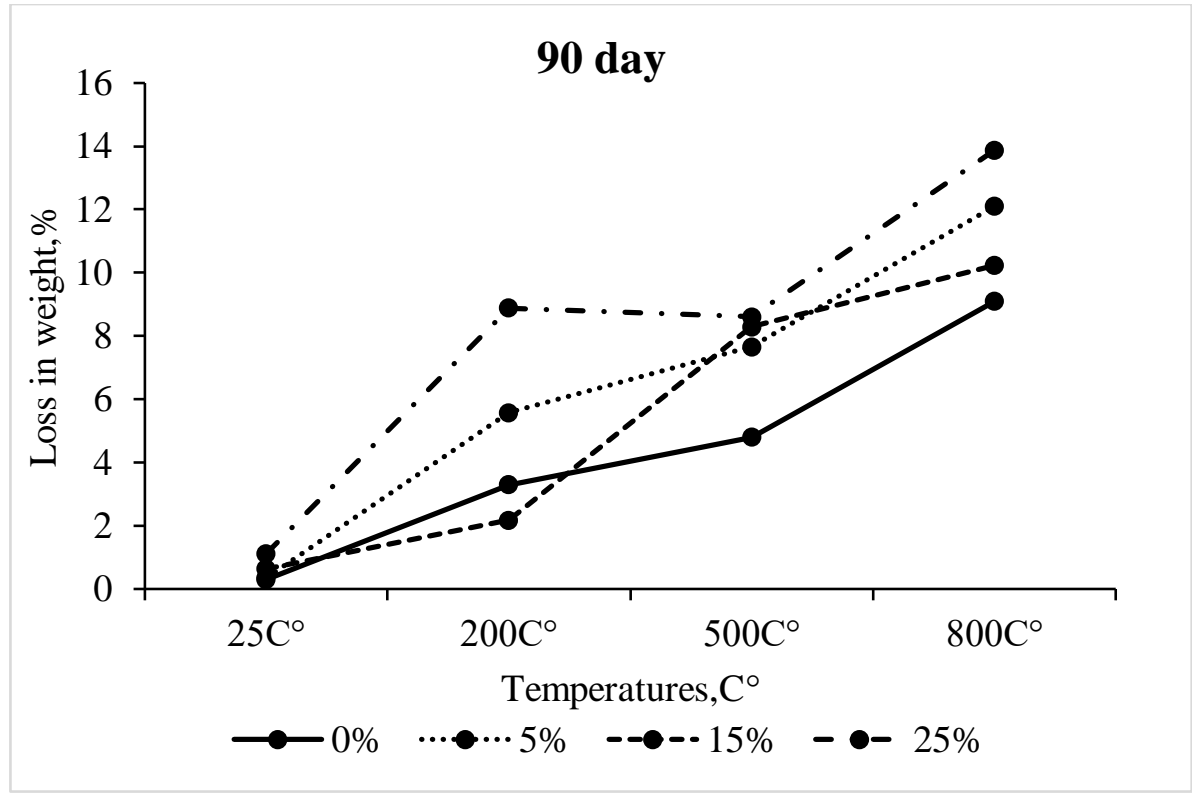

469

Fig.(6):The percentage of loss in weight of specimens at 90 days age exposed to various temperatures

471

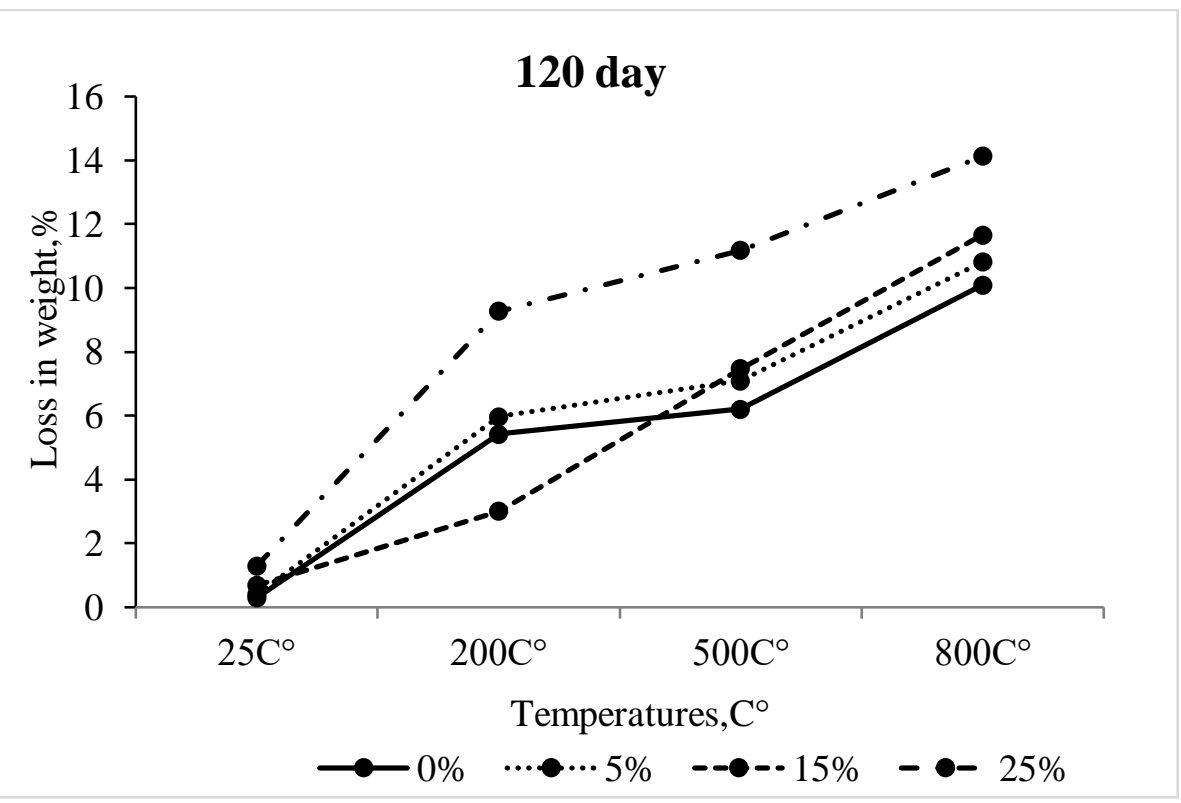

473

Fig. (7): The percentage of loss in weight of specimens at 120 days age exposed to various temperatures 


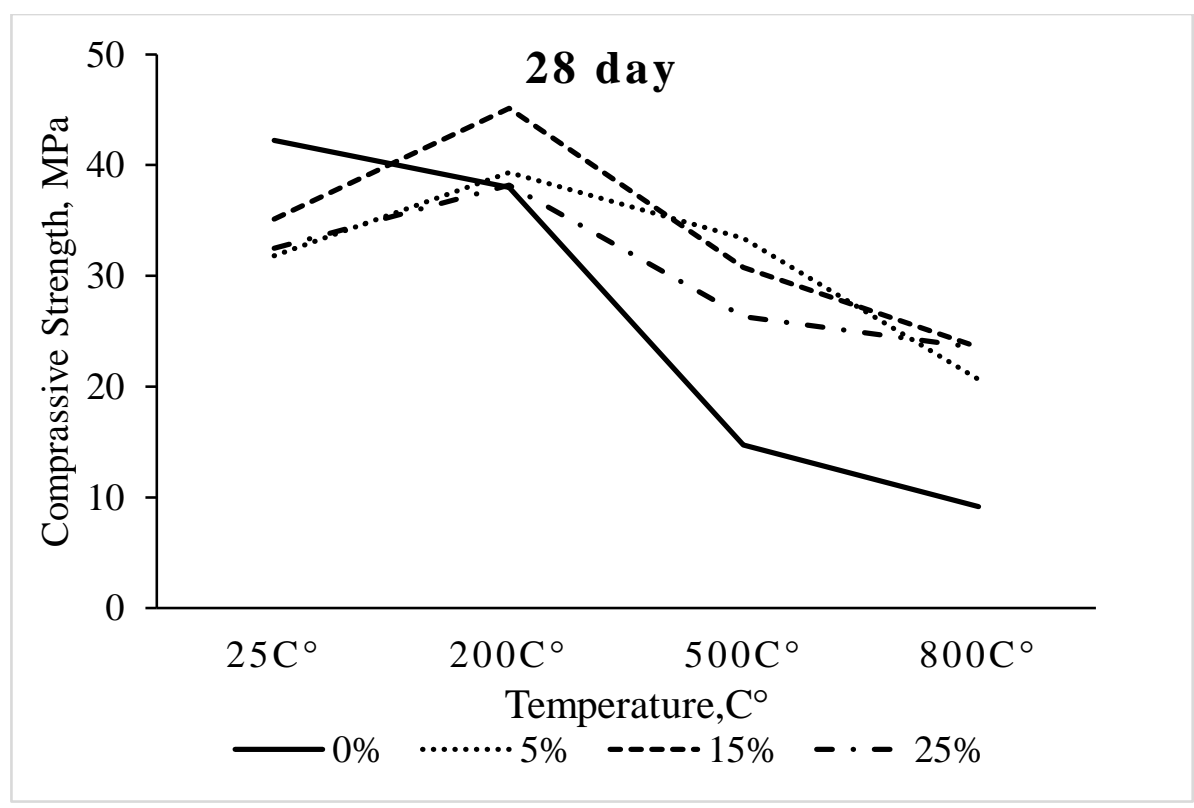

Fig.(8) : Relationship between the compressive strength on 28-days age and different elevated temperatures.

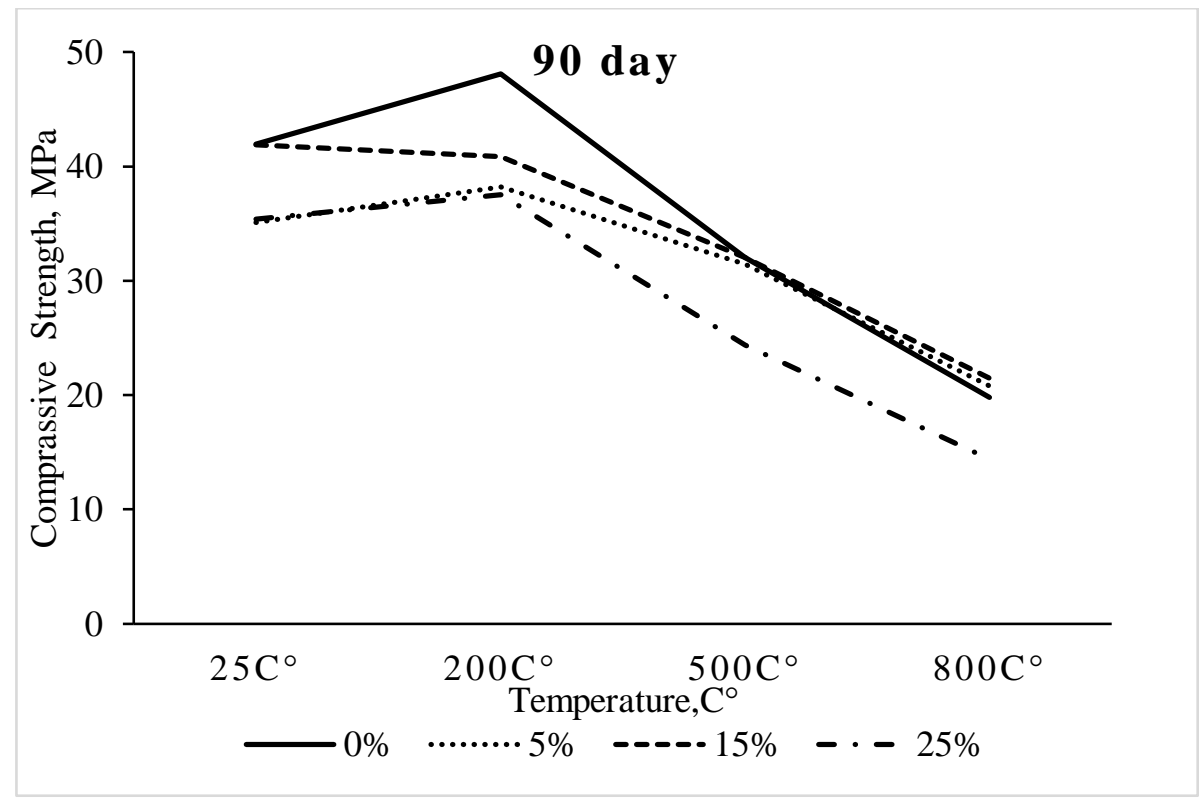




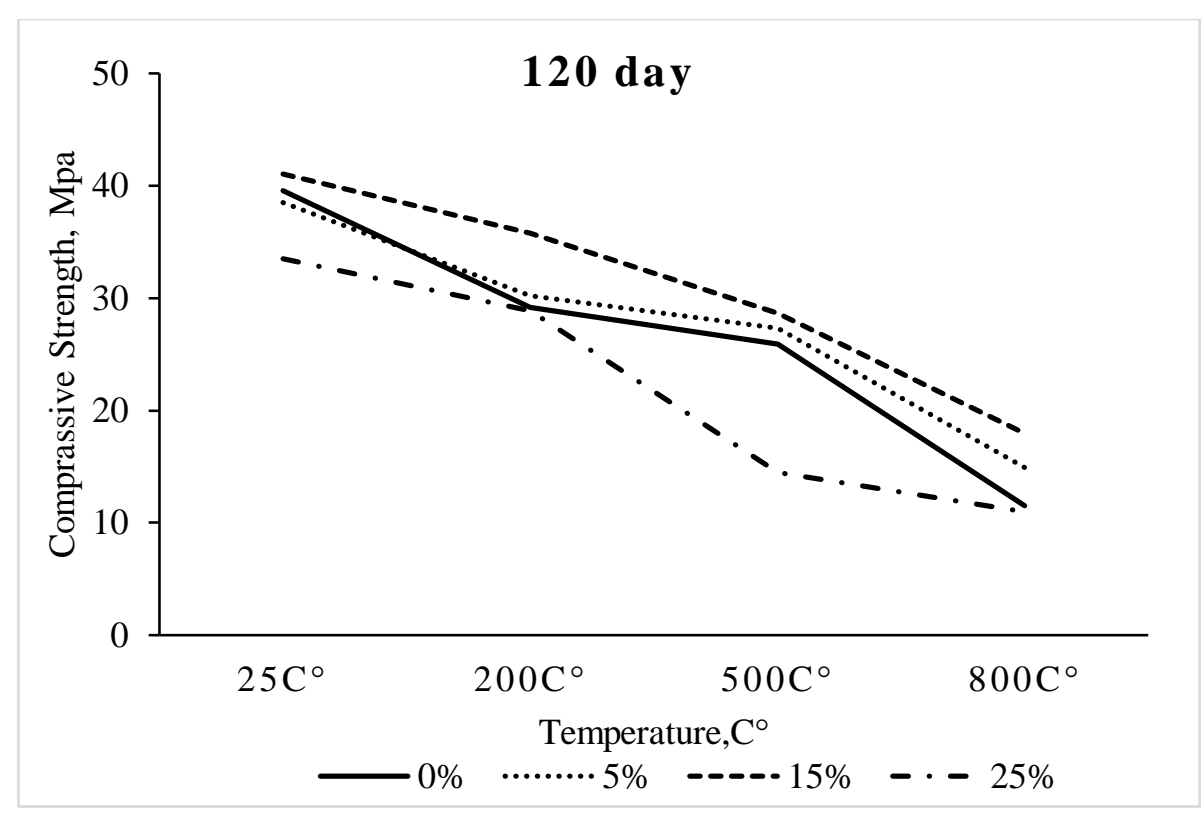

Fig.(10): Relationship between the compressive strength on 120-days age and different elevated temperatures.

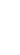

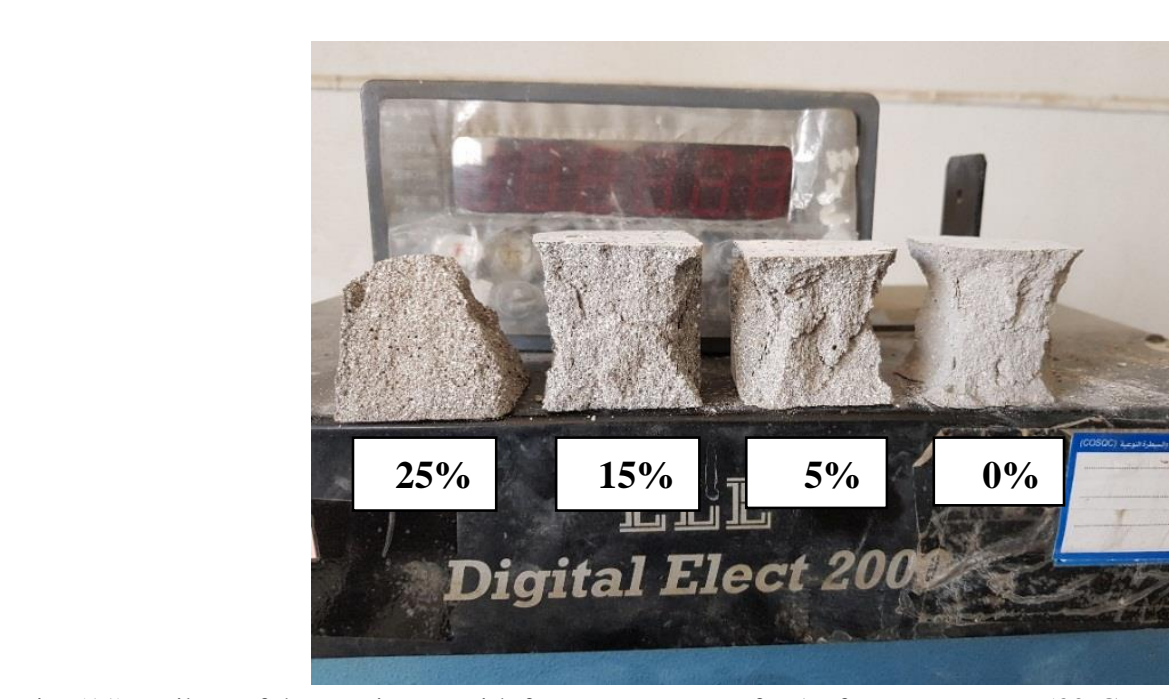

Fig. (11): Failure of the specimens with four percentages of VA after exposure to $500{ }^{\circ} \mathrm{C}$. 


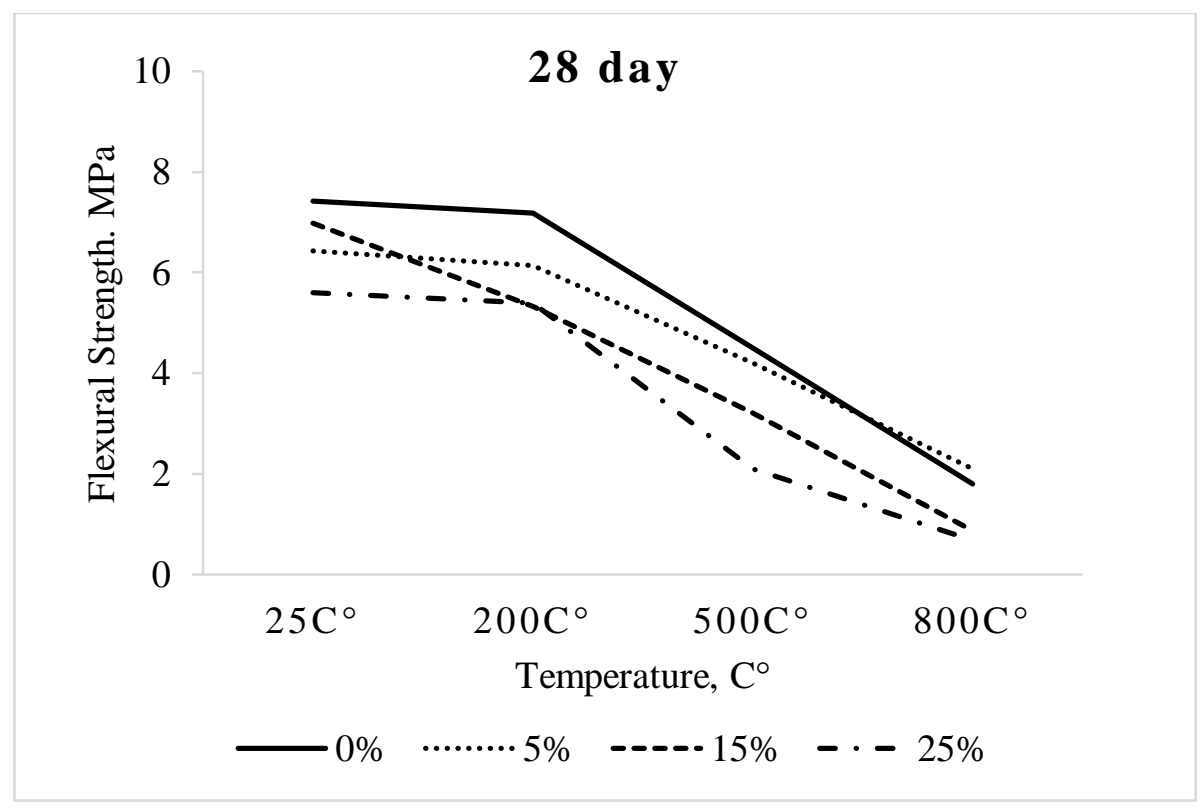

Fig.(12) : Influence of different elevated temperatures on the flexural strength on 28-days age

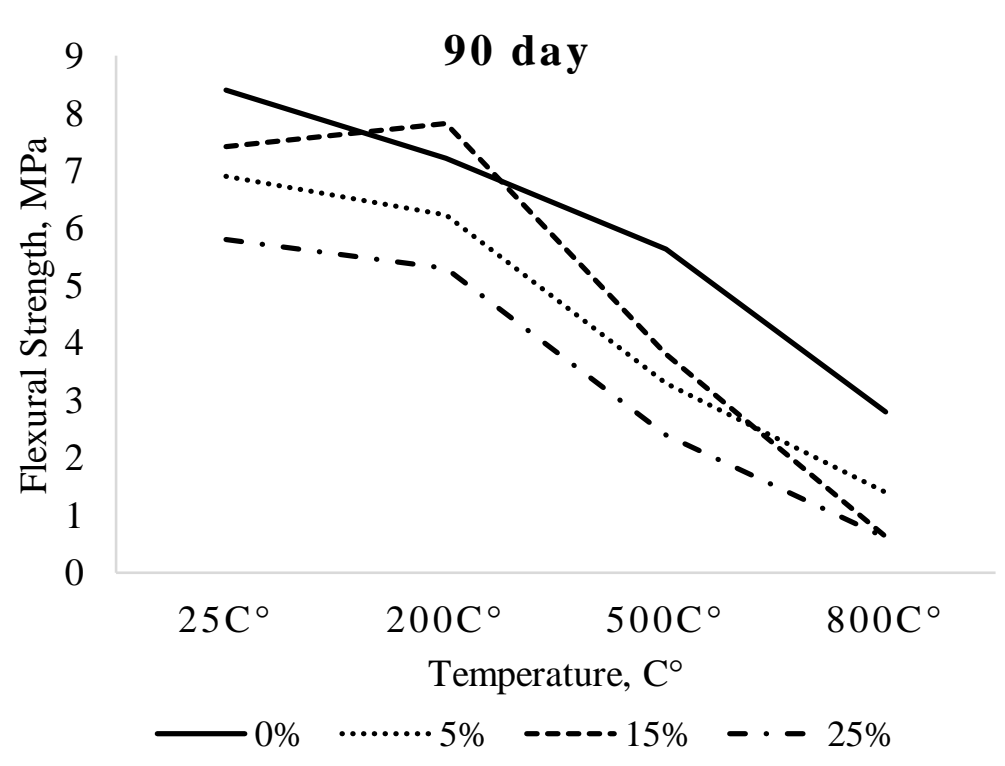

Fig.(13) : Influence of different elevated temperatures on the flexural strength on 90-days age 


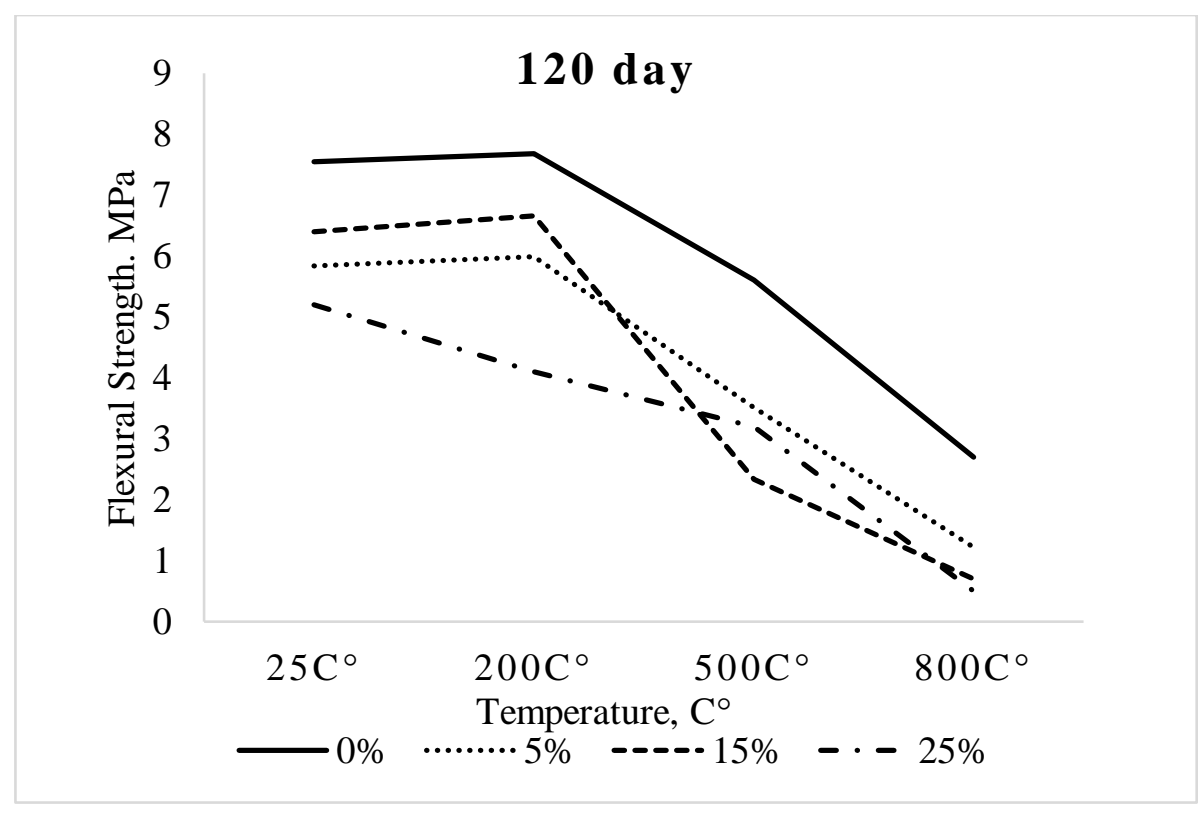

Fig.(14) : Influence of different elevated temperatures on the flexural strength on 120-days age

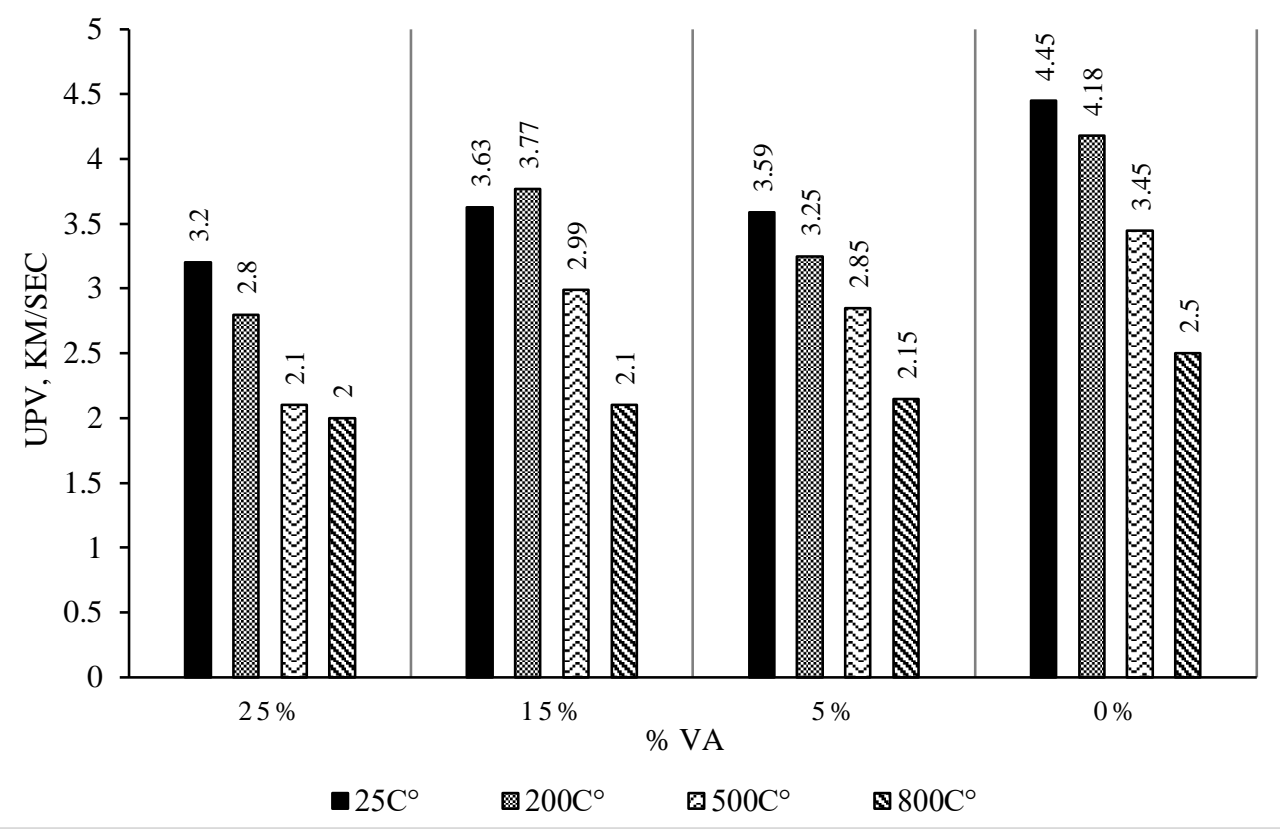

Fig. (15): UPV of mortar specimens exposed to different temperatures at 28-days age for all mixes. 


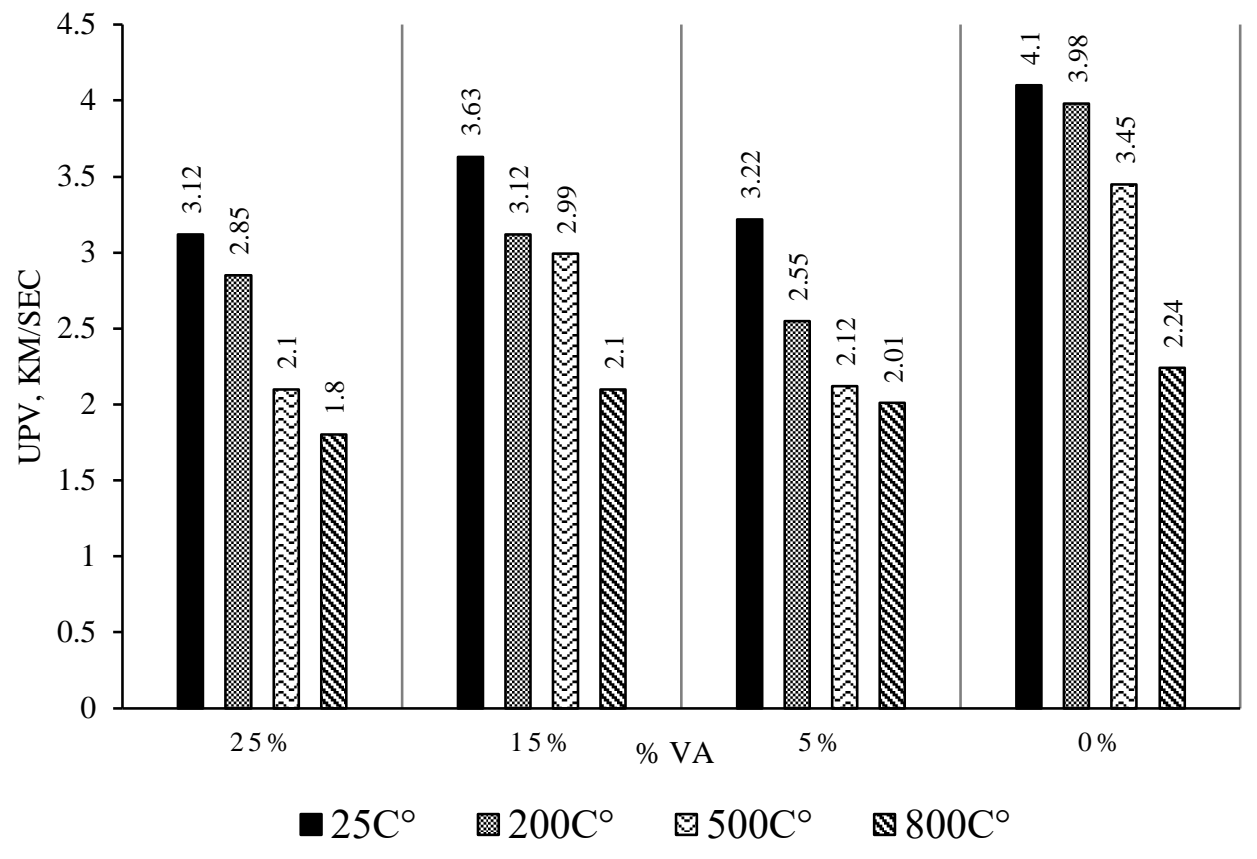

Fig. (16): UPV of mortar specimens exposed to different temperatures at 90-days age for all mixes.

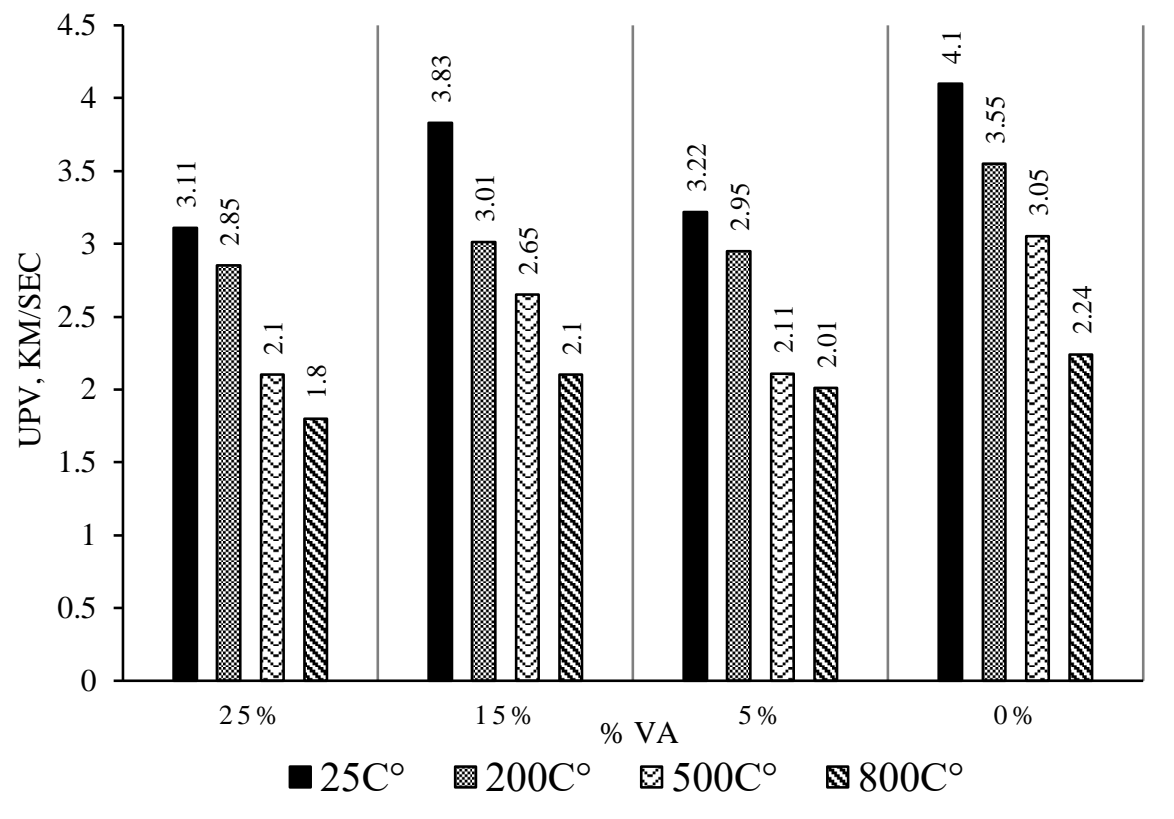

Fig. (17): UPV of mortar specimens exposed to different temperatures at-120 days age for all mixes. 